Kolmer, W.-Zeits. f. d. ges. Anat., Abt. 1, Vol. XCIII, p. 679, 1930.

Krause, A. C., and Sidwf.Ll, A. E.-Amer. Jl. Physiol., Vol. CXXI, p. 215, 1938.

KRIES, J., v.-Arch.f. Ophthal., Vol. XLII, p. 95, 1896.

KÜHNE, W.-Heidelberg Physiolog. Untersuch., Vol. I, p. 1 et seq., 1877-78.

Lythgoe, R. J.-Jl. Physiol., Vol. LXXXIX. p. 331, 1937.

MAITRA, M. K., and HARRIS, L. J.-Lancet, Vol. CCXXXIII, p. 1009, 1937.

Mutch, J. R., and GRIfFith, H. D.-Brit. Med. Jl. (i), p. 565, 1937.

OSTERBERG, G.- " Topography of the layer of rods and cones in the human retina." Copenhagen, 1935.

OWen, H. B., and Hennessey, R. S. F.-Trans. Roy. Soc. Trop. Med. and Hyg., Vol. XXV, p. 367, 1932.

Palmer, C. E.-Amer. Jl. Pub. Health, Vol. XXVIII, p. 309, 1938.

PaRINAUD, M.-Compt. rend. d. l'Acad. d. Sci., Vol. XCIII, p. 286, 1881.

Purkinje, J.- " Neue Beiträge zur Kenntnis des Sehens in subjektiver Hinsicht." Berlin, 1825.

Schultze, M.-Arch.f. mikroskop. Anat., Vol. II, pp. 165 and 175, 1866.

Studnitz, G., v.-Pfiüger's Arch., Vol. CCXXX, p. 61.3, 1932.

- Pflüger's Arch., Vol. CCXXXIX, p. 515, 1937.

Sugita, Y.-Arch. f. Ophthal., Vol. CXV, p. $260,1925$.

TANsley, K.-Jl. Physiol., Vol. LXXI, p. 442, 1931.

- Proc. Roy. Soc., B., Vol. CXIV, p. 79, 1933.

- Biochem.Jl., Vol. XX, p 839, 1936.

Trendelen BuRg, W.-Ergebin. Physiol., Vol. XI, p. 1, 1911

VERHOEFF, F. H.-Arch. of Ophthal., Vol. V, p. 392, 1931.

WALD, G.-Jl. Gen. Physiol., Vol. XIX, p. 351, 1935.

Nature, Vol. CXL, p. 545, 1937.

Jl. Gen. Physiol., Vol. XXI, p. 795, 1938.

Walls, G. I.-Amer. Jl. Ophthal., Vol. XVII, p. 892, 1934.

WRIGHT, R. E - Lancet, Vol. CIX, p. 800, 1931.

\title{
THE CHEMICAL EQUILIBRIUM OF THE INTERSTITIAL FLUIDS AND THE AQUEOUS HUMOUR*
}

BY

J. Douglas Robertson, M.D.

LONDON

FROM THE COURTAULD INSTITUTE OF BIOCHEMISTRY,

MIDDLESEX HOSPITAL, W.I

THE chemistry of the various biological fluids is of importance, for chemical analysis is another method of determining the nature of the various fluids throughout the body. It is proposed to limit the discussion only to certain aspects of this problem, namely :-

1. The chemical equilibrium that exists between blood and lymph.

2. The chemical equilibrium that exists between blood and gastric juice.

3. The chemical equilibrium that exists between blood and the aqueous humour. \footnotetext{
1938.

* Lecture delivered at the Royal London Ophthalmic Hospital, November 18,
,
} 
The first is an example where simple dialysis or ultra-filtration alone play a part in the production of the fluid. The simple physical laws governing the production of dialysates have already been described-Robertson (1939).

The second is an example of a typical secretion.

The third we shall call the unknown.

Before going on to a general discussion of the chemistry of these different fluids of the body, I would like very briefly to refer to the Donnan equilibrium, or as it is sometimes called-the Gibbs-Donnan equilibrium.

This term is mentioned a great deal when chemical analyses are being discussed, and it is usual for most text-books to describe it in the following way. The following diagram represents two electrolytes $\mathrm{NaR}$. and $\mathrm{NaCl}$ separated by a membrane indicated by this vertical line.

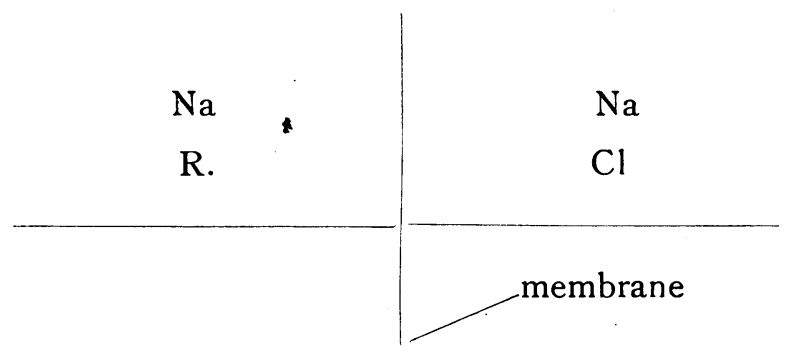

Let us assume that these solutions have just been separated from one another by this membrane. Now if the membrane does not allow the anion $\mathrm{R}$. of the salt $\mathrm{NaR}$. to pass through it, but allows all the other ions and salts to do so, then when equilibrium has been established, the following will be the state of the various ions.

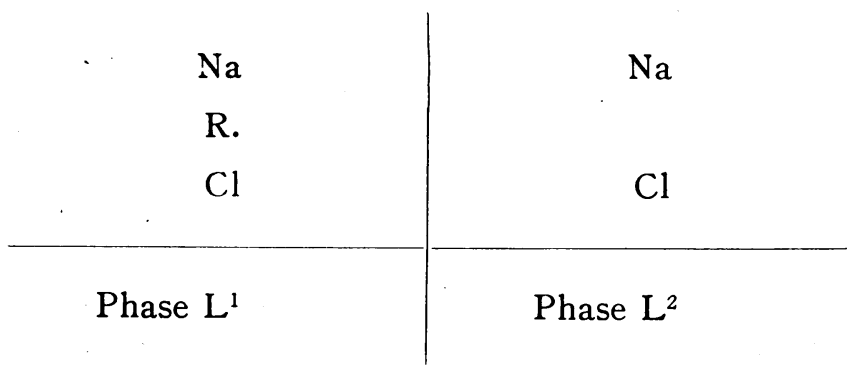

The solution containing the impermeable anion $\mathrm{R}$. to the left of the above membrane is known as " phase $\mathrm{L}^{1}$," while that on the other side is known as " phase $\mathrm{L}^{2}$." 
In a word, the Gibbs-Donnan theory of equilibrium put very simply is this.

"The product of any pair of diffusible cations and anions on one side of the membrane is equal to the product of the same pair of cations and anions on the other side "-or that$[\mathrm{Na}]_{1} \times[\mathrm{Cl}]_{1}=[\mathrm{Na}]_{2} \times[\mathrm{Cl}]_{2}$

where the concentrations of $\mathrm{Na}$ and $\mathrm{Cl}$ are expressed in grams molecules per litre of solutions.

On the side of the membrane containing the non-diffusible substance $R[\mathrm{Na}]_{1}$ is the sum of :

1. The cations formed by the splitting up of $\mathrm{NaR}$.

2. The cations formed by the splitting up of $\mathrm{NaCl}$.

On the other side of the membrane $[\mathrm{Na}]_{2}$ is the concentration of cations only in combination with $[\mathrm{Cl}]_{2}$.

It therefore follows from the above that in the phase $\mathrm{L}^{\mathbf{1}}$ the concentration of $[\mathrm{Na}]_{1}$ must exceed that of $[\mathrm{Cl}]_{1}$ (because some of the $\mathrm{Na}$ comes from the protein in addition to the $\mathrm{Cl}$ ).

In the phase $\mathrm{L}^{2}$ the $[\mathrm{Na}]_{2}$ and $[\mathrm{Cl}]_{2}$ must be equal. Since the products of the concentrations are the same in both phases it follows that $[\mathrm{Na}]_{1}$ which is greater than $[\mathrm{Cl}]_{1}$ must be greater than $[\mathrm{Na}]_{2}$ and that $[\mathrm{Cl}]_{1}$ must be less than $[\mathrm{Cl}]_{2}$.

$$
\text { i.e., } \quad \begin{aligned}
{[\mathrm{Na}]_{1} } & >[\mathrm{Na}]_{2} \\
{[\mathrm{Cl}]_{1} } & <[\mathrm{Cl}]_{2}
\end{aligned}
$$

The Gibbs-Donnan equilibrium, determines therefore, the distribution of ions across a membrane which is permeable to some ions and impermeable to others. Many experiments carried out in ritro between protein and salt solutions with semi-permeable membranes have confirmed the equilibrium described abovenamely, that on the side of the membrane where there is protein, the cations-e.g., sodium is greater than on the other; and again, the anions-e.g., chloride are greater on the side of the membrane where there is no protein.

This chemical equilibrium was carried a step further by van Slyke and his colleagues (1925) who employed it to explain the uneven distribution of ions between biological fluids such as blood plasma and lymph and the other body fluids. The vascular membrane of the capillary they maintained is a simple semipermeable membrane allowing the free passage of all anions and cations with the exception of proteins and lipoids. The distribution of electrolytes and non-electrolytes between blood plasma and its ultrafiltrates should therefore conform with reasonable accuracy to the Gibbs-Donnan predictions. In terms of the various substances present in blood, the Gibbs-Donnan predictions are :-

1. Freely diffusible non-electrolytes such as non-protein nitrogen, urea, uric acid, creatinine and sugar are evenly distributed between plasma and its ultrafiltrates. 
2. On the blood side of the capillary membrane one would expect more cations such as sodium, potassium, calcium, and magnesium.

3. On the ultrafiltrate side of the membrane there should be more anions such as phosphate, chloride and sulphate.

4. The product of any pair of diffusible cations and ions on one side of a membrane is equal to the product of the same pair of cations and anions on the other. For the purposes of this equation we shall adhere only to the simple product of $\mathrm{Na}$ and $\mathrm{Cl}$.

The Chemical Composition of Lymph.-It is generally recognised that lymph is formed from blood plasma by simple filtration through the capillary wall. That being so the chemical composition of lymph should resemble that of an ultrafiltrate of blood dialysed in vitro. Since 1925, several workers have made complete chemical analyses of lymph and chief among these has been Drinker and his colleagues (1935) (1933) at Harvard. In making a chemical comparison between blood and lymph, these workers have emphasised the importance of the following conditions which many experimentalists completely disregard.

1. Lymph must be compared with blood plasma-not with whole blood. The reason is that there is an unequal distribution of substances in the blood between corpuscles and plasma and it is the plasma part of the blood with which the body fluids would come into equilibrium.

2. The values for the various substances must be expressed in terms of the water contents of the fluids. This correction is most important where there is a protein molecule on one side of the membrane and not on the other. The protein molecule is so large that its water displacement may introduce an error.

To give an example. -100 c.c. of blood cells contain only 72 grams water. 100 c.c. of blood plasma contain only 93.5 grams water. 100 c.c. of cerebro-spinal fluid contain 99.6 grams water. The variations in the water content is due to the fact that blood cells contain 32.3 grams per cent., plasma 7 grams per cent., and cerebro-spinal fluid 0.02 grams per cent. of protein. The protein molecule, therefore, takes up space and dilutes the concentration of substances if estimated only in terms of per 100 c.c. of a particular fluid.

3. Blood and lymph samples can never be taken simultaneously for it takes time for lymph to flow from the site where it is formed to the cannula.

\section{Chemical Composition of Lymph}

1. Protein.-The first point of importance is that there is less protein present in lymph than in blood plasma. This gradient in the protein concentration is not unexpected, for the capillary 
membrane is a so-called semi-permeable membrane and holds back the plasma proteins. It is probable that if a sample of tissue fluid was obtained-that is the fluid as it filters through the capillary wall, it would contain less protein than that of lymph, because the absorption of water and salts by the capillary wall tends to increase the concentration of any protein in the tissue spaces; and it is the unabsorbed fluid that is left in the tissue spaces that enters the lymphatic capillaries to become lymph. Unfortunately, it is not possible to get samples of tissue fluid. However, other than their protein content, there can be little difference in the respective chemical compositions of lymph and tissue fluid.

2. Freely diffusible non-electrolytes.-Most workers agree that in animals under normal conditions, freely diffusible substances such as non-protein nitrogen, urea, creatinine, uric acid and sugar occur in almost identical concentrations in the plasma and lymph. The following tables ( 1 to 3 ) from analyses by Arnold and Mendel (1927) give comparisons between the sugar and non-protein nitrogen of the lymph and blood plasma under various normal and experimental conditions.

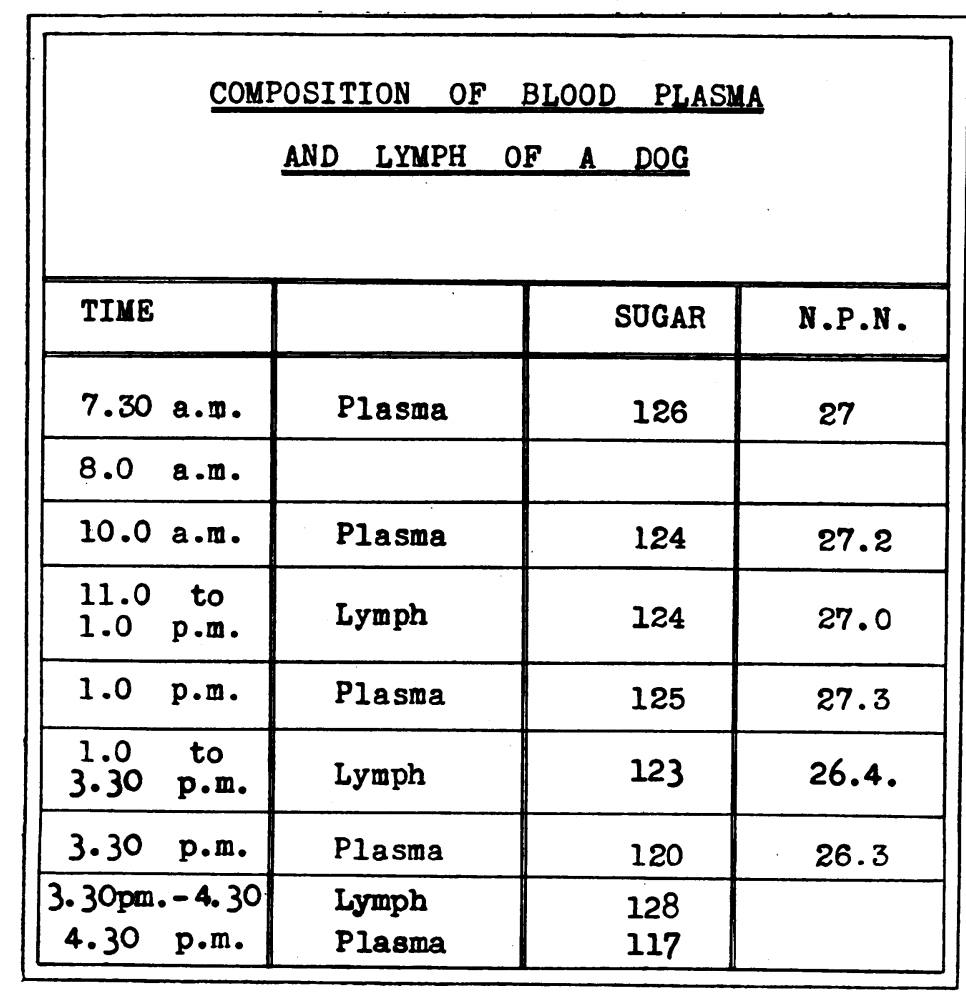

FIG. 1. 
Interstitial Fluids and The Aqueous Humour 175

It can be seen from Fig. 1 that these substances occur in almost identical concentrations under normal laboratory conditions.

In addition to these observations on the intact animal, the changes in the chemical composition of lymph and blood have been studied after the various constituents of the blood have been artificially altered. It has been found that as the concentration of the various substances in the blood altered comparable changes occurred in the lymph at the same time There are several methods that have been employed to bring about these changes and they include :-

1. Exclusion of the kidney function.-The kidney function was excluded by ligation of the ureters and renal vessels and as a result the non-protein nitrogenous constituents accumulated in the blood. The following figure summarises the changes which occurred.

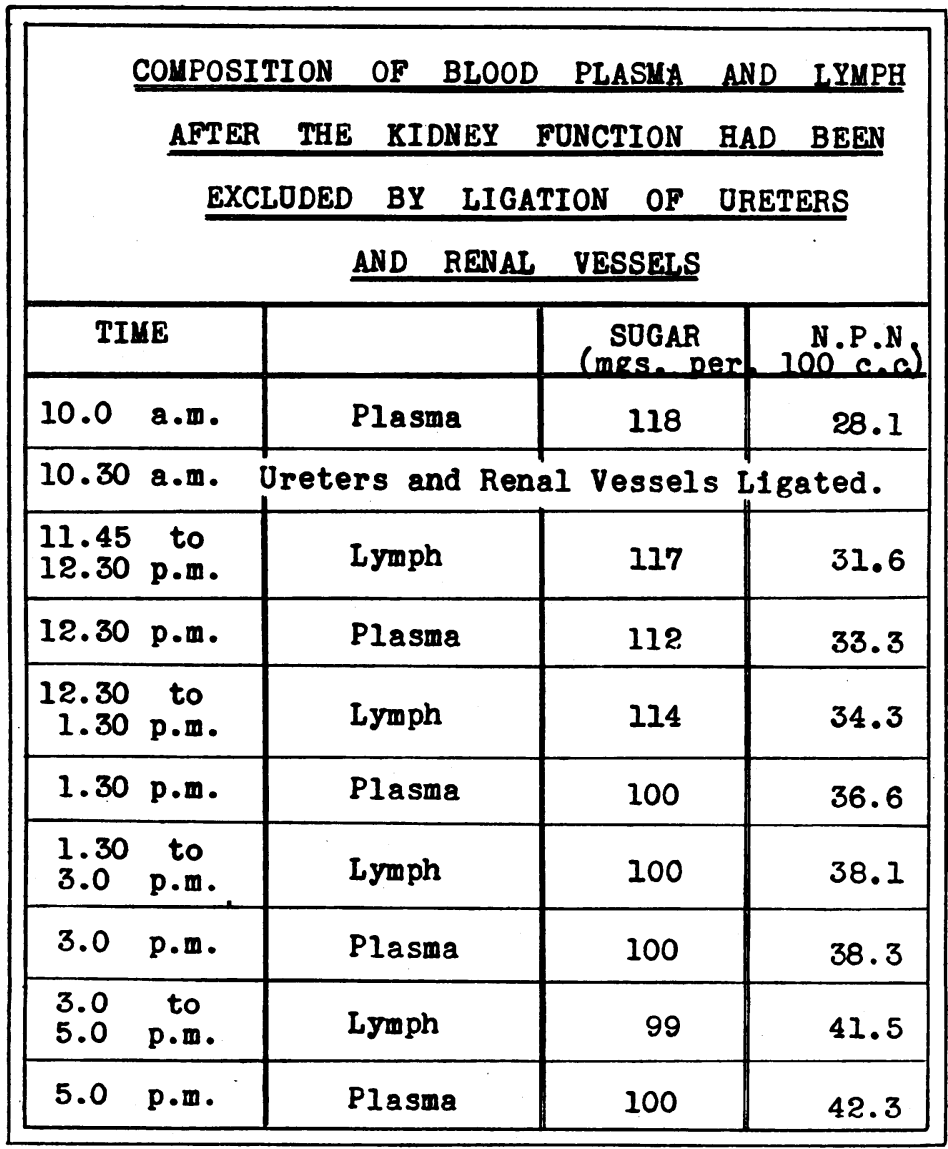

FIG. 2. 
The table in Fig. 2 shows that as the non-protein nitrogen accumulated in the blood, so its concentration rose to the same degree in the lymph. It follows, therefore, that the interchanges of the non-protein nitrogen must take place very promptly between these two fluids. I should explain that the non-protein nitrogen includes constituents such as urea, creatinine, uric acid, aminoacid nitrogen.

2. Injection of insulin.-It is well known that soon after the subcutaneous injection of insulin the blood sugar begins to fall. The following table shows the sugar in the blood and lymph following insulin administration.

It can be seen from Fig. 3 that the lymph sugar intimately follows the fall in the blood plasma sugar. It is, of course, difficult to obtain exactly corresponding values because the lymph must be collected over a certain period of time. The following figure from the work of Heim and Berg (1933) shows the changes in plasma sugar and lymph obtained from the subcutaneous vessels at frequent intervals after the insulin injection. It will be noted that as soon as the insulin takes effect, the lymph sugar follows very closely that of the plasma.

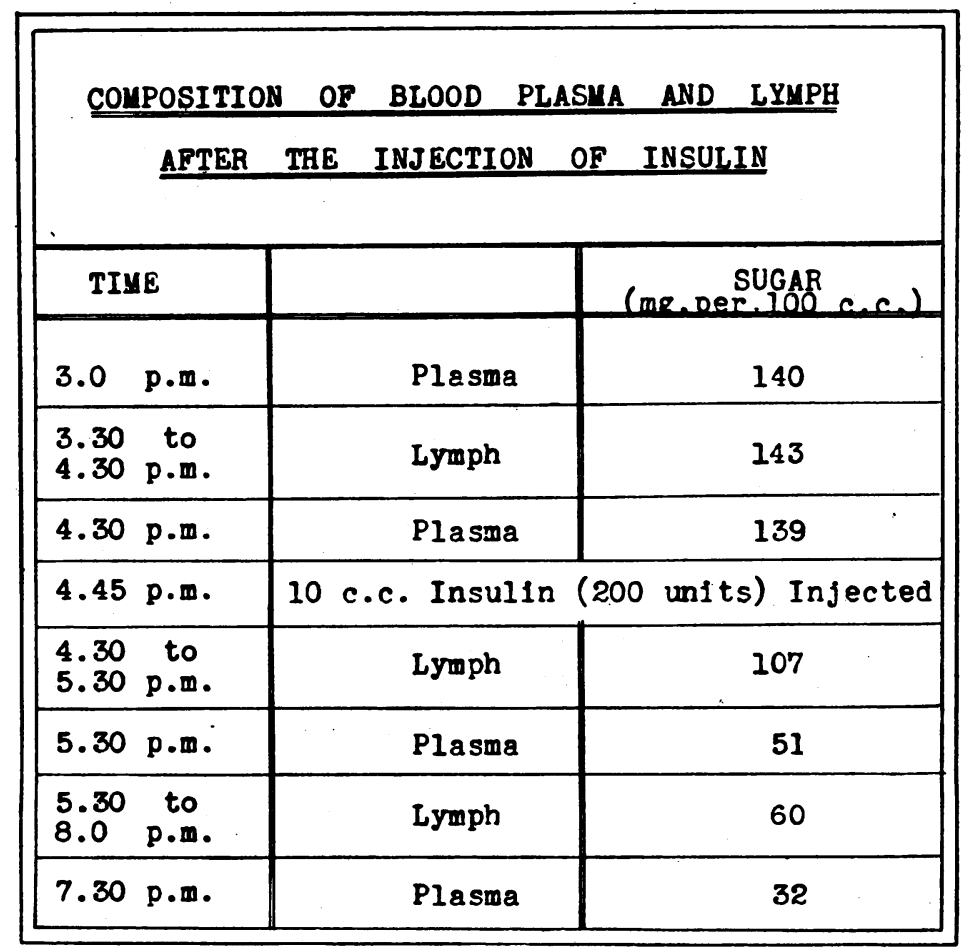

FIG. 3. 

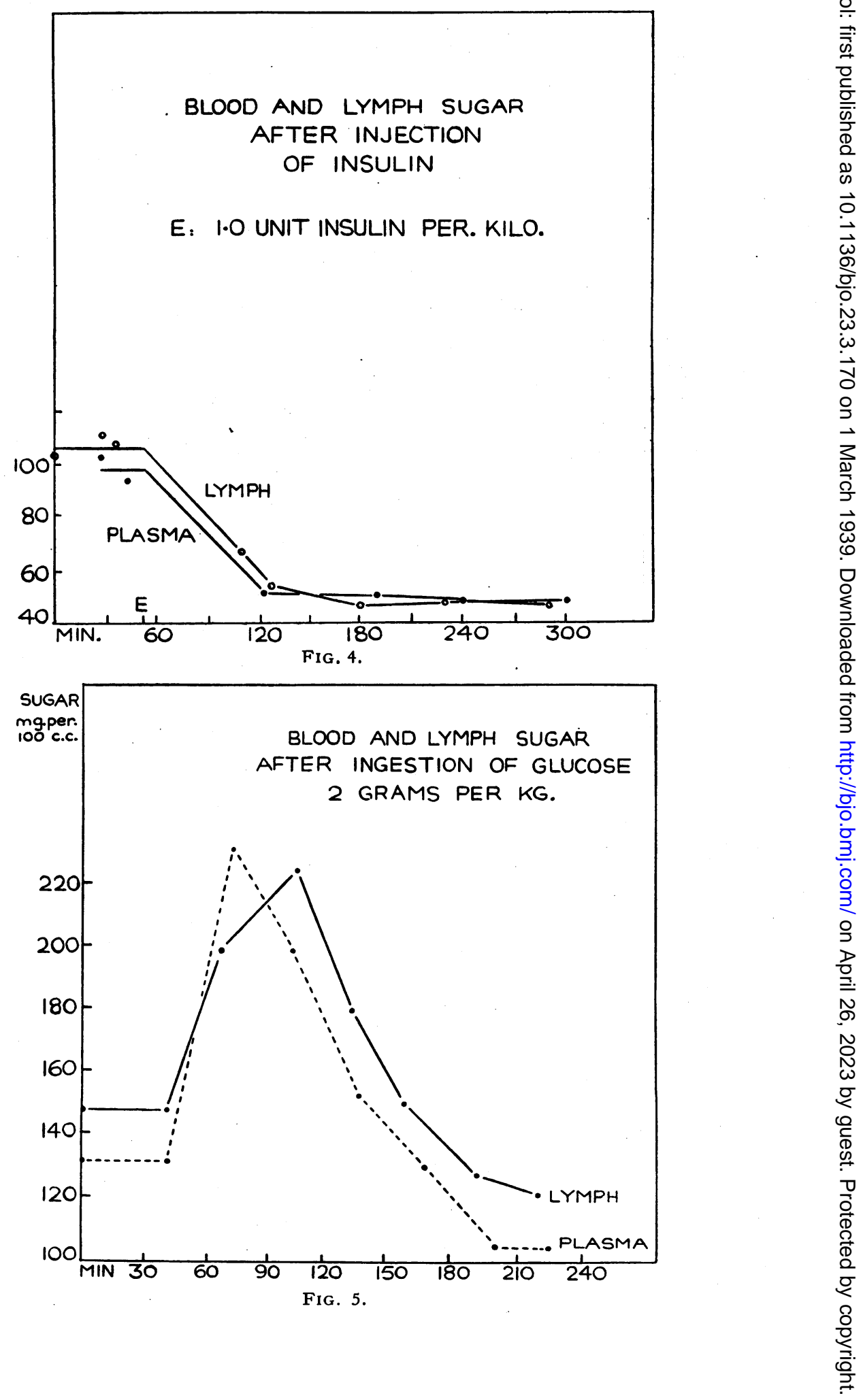
3. Administration of sugar.-Following the administration of sugar by mouth or intravenously, there is a rapid rise followed by a fall in the plasma sugar. The following figure from Heim el al. (1935) shows the variations in plasma and lymph sugar after the ingestion of glucose by mouth.

It can be seen from Fig. 5 that the sugar enters the lymph stream rapidly as indicated by the almost parallel rise in lymph and plasma curves. The fall in lymph sugar follows closely that of the plasma-any slight discrepancy no doubt being due to a time-lag.

There can, therefore, be no doubt that regarding the diffusible non-electrolytes the concentration of these substances in the lymph intimately follows that in the plasma and the capillary membrane behaves in no way different from that of a semi-permeable membrane in vitro.

4. The distribution of cations.-The following table illustrates a comparison of the concentrations of certain cations in blood plasma and lymph, or for that matter any interstitial fluid such as ascitic fluid. It is seen from Fig. 6 that there are more cations

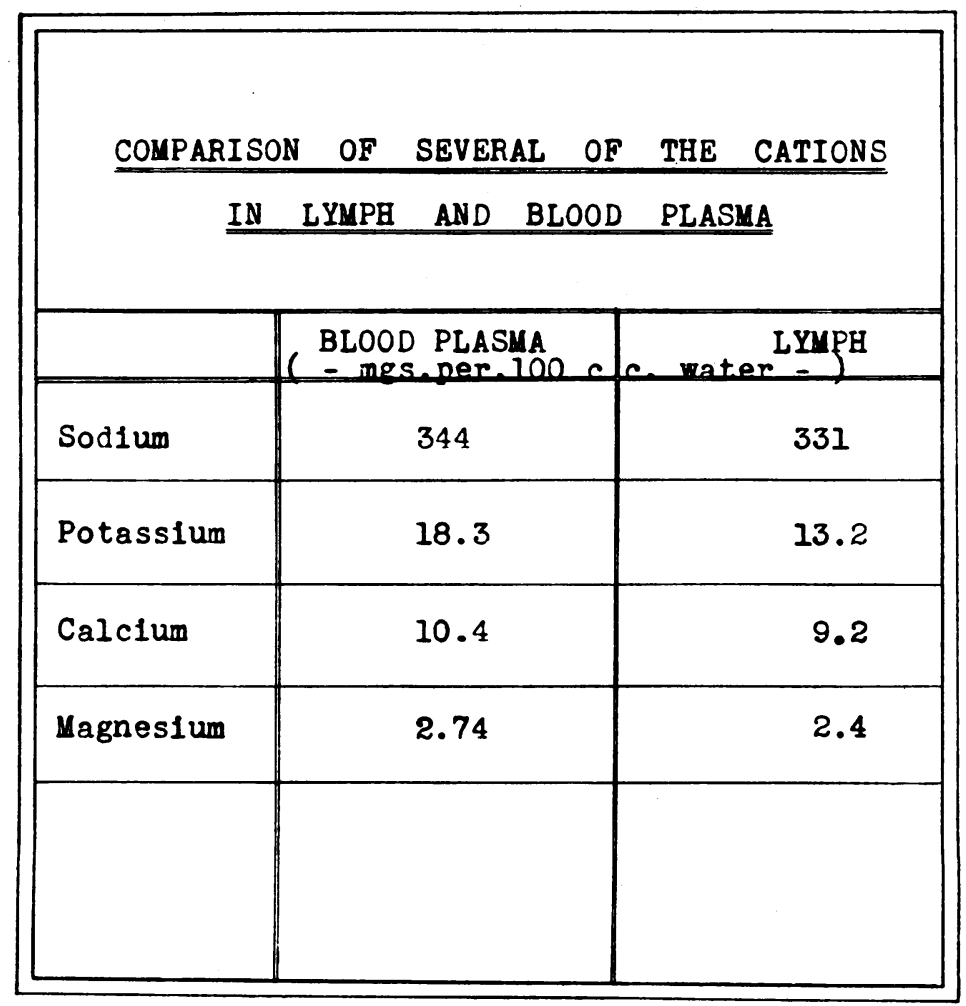

FIG. 6. 
in the serum than in the lymph, thus indicating that their distribution is possibly in accord with the predictions of the GibbsDonnan equilibrium.

I should like to discuss in greater detail the nature of the calcium concentration in lymph and blood plasma, as this will have an important bearing when the chemistry of the aqueous humour is discussed. It has been shown by test-tube experiments that the disparity in the lymph calcium is almost certainly due to the combination of this element with protein. Dialysis and ultrafiltration experiments carried out by many workers have clearly demonstrated that a certain portion of the calcium in blood plasma cannot diffuse through a semi-permeable membrane, and that the amount of this calcium varies directly with the amount of protein. We therefore speak of calcium as being present in two forms in the blood.

1. The undissociated or indiffusible form.-This is the calcium adsorbed on to protein and it is sometimes called calcium proteinate.

2. The dissociated and freely diffusible form.-It is obvious that the concentration of the calcium, free to diffuse through a membrane, be it a collodion membrane or the wall of a capillary, will depend on the amount present of-

1. Protein.

2. Total calcium.

Arnold and Mendel (1927) made a very complete study of the variations in the serum and lymph calcium in animals after experimental alterations in their calcium metabolism. These authors produced hypocalcaemia in animals by removal of their parathyroid glands, and in contrast hypercalcaemia by the subcutaneous injection of parathormone-the active extract of parathyroid glands.

The following figure shows the effects of these experiments on the calcium of the blood and lymph.

From Figs. 7 and 8 it can be seen that following alterations in the calcium metabolism, the calcium of the lymph and serum changed in the same direction and to approximately the same degree.

4. The distribution of anions.-Most attention has been paid to the concentration of chlorides and all workers agree that there is a higher concentration of chlorides in lymph with respect to plasma. The ratio-

chloride in serum - is about 0.95 and may be interpreted in terms of the Donnan equilibrium as being due to the higher protein content of the plasma. 
The phosphate ratio of $-\frac{\text { phosphate of serum }}{\text { phosphate of lymph }}$-is also about 0.95. Analyses on sulphate are not very satisfactory, but there seems no reason to doubt that the sulphate ratio would not lie in the same direction.

5. The distribution ratio of anions and cations.-Of great importance in the distribution of the various ions is the product of pairs of diffusible cations and anions. It is unnecessary to burden you with any more figures so I shall simply state that all workers agree that in most cases the product of a pair of diffusible cations and anions in the lymph is equal to the product of these same pair in blood plasma. Or to take a simple example-the product of $\mathrm{Na}$ (sodium) and $\mathrm{Cl}$ (chloride) in lymph and plasma is the same, the concentrations of these ions being of course expressed in gram molecules per litre. $\mathrm{Na}$ and $\mathrm{Cl}$ are chosen as they can be analysed more accurately than the other ions.

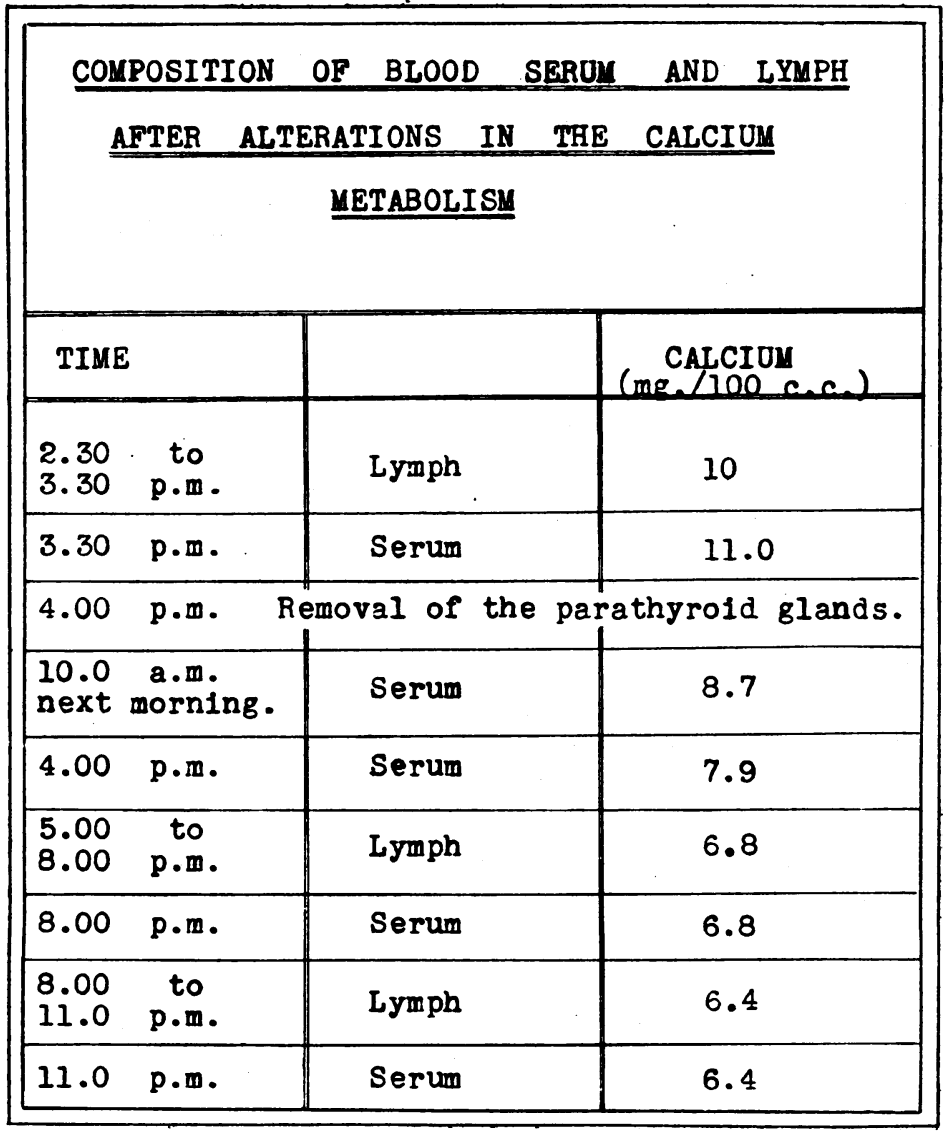

FIG. 7. 
Interstitial Fluids and The Aqueous Humour

\begin{tabular}{|c|c|c|}
\hline COMPOSITIO & N OF BLOOD & SERUM AND LYMPH \\
\hline AFTER & INJECTION OF & PARATHORMONE \\
\hline TIME & & (mo CALCIUM \\
\hline $\begin{array}{l}4.00 \text { to. } \\
5.30 \text { p.m. }\end{array}$ & Lymph & 10.2 \\
\hline 5.30 p.m. & Serum & 11.4 \\
\hline 7.00 p.m. & 10 c.c. parath & tormone subcutaneously \\
\hline $\mid \begin{array}{ll}7.45 & \text { a.m. } \\
\text { hext morning. }\end{array}$ & Serum & 16.4 \\
\hline $\begin{array}{l}11.30 \text { to } \\
1.00 \text { p.m. }\end{array}$ & Lymph & 15.9 \\
\hline 12.0 noon & Serum & 17.6 \\
\hline $\begin{array}{ll}1.00 & \text { to } \\
3.00 & \text { p.m. }\end{array}$ & Lymph & 16.1 \\
\hline 3.00 p.m. & Serum & 17.8 \\
\hline
\end{tabular}

FIG. 8.

The conclusions we draw on the nature of the lymph from its chemical composition is as follows :-

1. The chemical equilibrium between plasma and lymph is exactly the same as if these two solutions were on opposite sides of a collodion or other semi-permeable membrane.

2. A simple ultrafiltration or dialysis of blood plasma through the capillary wall adequately explains the mode of formation and chemical composition of the lymph.

3. These deductions based on the chemical composition are in accord with those based on the physical equilibrium which I mentioned in my first lecture-namely, that the lymph is a dialysate of the plasma.

The chemical composition of gastric juice.-The first point of practical and theoretical importance is that the osmotic pressure of gastric juice is the same as that of blood plasma. Several observers have concluded that because the osmotic pressure of a particular fluid was approximately the same as the plasma, then 
that fluid must needs be a dialysate of the plasma. 'This conclusion does not necessarily follow, for we find that all secretions with the possible exception of saliva are isotonic with blood. In other words, although fluids such as gastric juice, pancreatic juice, hepatic bile, aqueous humour, cerebro-spinal fluid, have each their characteristic chemical composition, the total molar concentration of the various substances of which they are composed, is the same as the blood. Gilman and Cowgill (1931-32) $(1933 a)(1933 b)$ have in addition shown that when the osmotic pressure of blood was raised or lowered by the injection of hypertonic $\mathrm{NaCl}$ or water, corresponding changes occurred in the gastric juice, bile, pancreatic juice and lymph.

It is well known by every student that the stomach secretes free hydrochloric acid and little else appears to be generally known about the chemical composition of the gastric contents; but its chemical composition will be dealt with in the same manner as that of lymph.

1. Protein.-Only very small amounts of protein have been found in the gastric juice and it is found chiefly in the form of mucin.

2. Freely diffusible non-electrolytes.-Most observers have found far less urea in the gastric contents than in plasma, but considerable amounts of ammonia have been detected in the stomach and this substance is not found in the blood. It has been suggested that the gastric mucosa contains urease, and that as the urea diffuses through into the stomach it becomes broken down into ammonia. I have found that the sum of the urea plus ammonia in the stomach of animals - chiefly cats, and in man is less than 50 per cent. of the blood urea.

With regard to the concentration of other diffusible constituents there is no information. It has been stated that no glucose is present in gastric juice, nor is glucose absorbed from the stomach. These points will be dealt with later. There is no doubt, however, that the stomach wall does not behave like a simple, semipermeable membrane and it follows that some more complicated mechanism than simple dialysis must be present which prevents the diffusion of such easily filterable substances as urea and sugar.

3. The distribution of cations.-The composition of the gastric juice varies in different parts of the stomach. In the fundus there is a very high concentration of free hydrochloric acid but with practically no sodium ; in the pyloric region the secretion is almost neutral and it contains equal amounts of sodium and chloride. The sodium content of the gastric juice is therefore much less than that of the plasma. The calcium content is lower and the potassium content much higher than that in the corresponding plasma. The distribution of the cations is not altogether in accord 
with the Donnan equilibrium for the cations in dialysates are only slightly lower than in the protein-rich fluid.

4. The distribution of anions. - The chloride makes up the major part of the ions and in pure gastric secretion the $\mathrm{Cl}$ content of the gastric juice is equal to the total base of the blood. It follows then, that there must be a far greater concentration of chlorides in gastric juice compared with plasma than can be explained on the Donnan equilibrium and by actual analysis this has been found to be the case. $\mathrm{Cl}$ would appear to be the only anion found in gastric juice with the exception of a trace of phosphates.

5. The distribution ratio of anions and cations.-Of importance, as well as the disparity in their respective ratio, is a comparison of the products of any pair of diffusible cations and ions in the gastric juice and the blood. The product of $\mathrm{Na}$ and $\mathrm{Cl}$ in the gastric juice does not equal the product of $\mathrm{Na}$ and $\mathrm{Cl}$ in the plasma, so that the distribution of $\mathrm{Na}$ and $\mathrm{Cl}$ is not in accord with the Gibbs-Donnan equilibrium.

The conclusions, on the nature of the gastric juice from its chemical composition are as follows :-

1. The chemical equilibrium between plasma and gastric juice is quite different from the equilibrium that would take place if these solutions were placed on each side of a collodion or other semi-permeable membrane.

2. Simple dialysis cannot adequately explain the formation of gastric juice. Some more complicated mechanism must be present to account for-

a. The production of free hydrochloric acid.

$b$. The prevention of the free diffusion of such easily filterable substances as urea and sugar.

3. The chemical findings against dialysis are in accord with those based on the physical equilibrium to which I referred in my first lecture.

\section{The Chemical Composition of the Aqueous Humour}

1. Protein.-There is very little protein present in the aqueous humour and it has been estimated to be about 0.02 grams as compared with 8.0 grams in plasma. The very low protein of the aqueous humour and cerebro-spinal fluid is believed to be due to the presence of a second membrane reinforcing the ciliary processes and choroid plexus respectively.

2. Freely diffusible non-electrolytes.-A great many analyses have been carried out on the sugar content of the aqueous and a few on the concentration of the non-protein nitrogen, urea, uric acid and creatinine. The most comprehensive study has been 
carried out by Walker (1933) working in Professor Richard's laboratory, and I cannot do better than quote freely from his results. He carried out 80 experiments upon frogs, fowls, rabbits, dogs, cats, and men, in which the composition of the aqueous humour was compared with that of blood from the same animal. He found :-

a. The sugar was less in the aqueous than in blood in all experiments, except those carried out on the rabbit. In rabbits, curiously enough, in three out of five animals, the sugar in blood and aqueous was the same. This chance agreement in the sugar contents of blood and aqueous in the rabbit has misled several workers into false premises.

$b$. The urea of the aqueous averaged 68 per cent. of that in the blood.

c. The uric acid of the aqueous averaged 66 per cent. of that in the blood.

The deficiency of urea, sugar, and uric acid, in the aqueous humour is very apparent from Walker's figures. There can be no doubt, therefore, that the membrane in the eye, intervening between blood plasma, and the intra-ocular fluid, does not behave like a simple semi-permeable membrane. If it did, then substances like urea, uric acid, and sugar should be found in the blood and aqueous in equal concentrations for they are freely diffusible and easily filtrable both in vivo and in vitro.

In addition to the above analyses on the sugar content some interesting experiments have been carried out on the sugar of the aqueous and the blood after insulin injections. It was found by Kirby, Wiener and Estey (1932) that during the rapid fall in the blood sugar after insulin the value of the aqueous humour sugar may exceed that of the blood, thus reversing the normal relationship. This is a further proof that the membrane in the eye between blood and aqueous is no simple membrane like a collodion type employed in vitro or like the capillary membrane in the tissue spaces throughout the body.

3. The distribution of cations.-The following table-see Fig. 9 -illustrates a comparison of the concentrations of certain cations in blood plasma and aqueous taken from an investigation by Tron (1928).

It will be seen that the amounts of sodium, potassium, magnesium and calcium are all lower in the aqueous humour than in the plasma, and it would appear that the principle of the GibbsDonnan equilibrium had been supported. Closer examination, however, reveals that this may not be so, for the disparity in potassium and calcium particularly is too great to be explained by simple dialysis. Another experiment has been carried out which makes it all the more unlikely that in the eye we are dealing with simple dialysing membrane. 
Interstitial Fluids and The Aqueous Humour

\begin{tabular}{|l|c|c|}
\hline \multicolumn{3}{|c|}{ COMPARISON OF THE CONCENTRATIONS } \\
\hline \multicolumn{3}{|c|}{ OF CERTAIN CATIONS IN BLOOD } \\
\hline PLASYA AND AOUEOUS \\
\hline CATIONS & PLASYA & AQUEOUS HUMOUR \\
\hline Sodium & 359 & 338 \\
\hline Potassium & 31 & 19 \\
\hline Calcium & 11.4 & 6.2 \\
\hline Magnesium & 1.6 & 1.05 \\
\hline
\end{tabular}

FIG. 9.

In dealing with lymph, the calcium of the lymph was found to be lower than the serum. This was explained by the fact that some calcium was adsorbed on to the protein, the calcium proteinate remaining indiffusible. When the blood calcium was raised by parathormone then the calcium of the lymph increased approximately to the same degree, and on the other hand when the blood calcium fell after parathyroidectomy a similar fall took place in the lymph calcium. These results showed that the portion of calcium joined to protein remained constant and that artificial alterations in the serum calcium level affected the diffusible calcium only because the fluctuations in the serum and lymph calcium were the same.

Now if a study is made of the aqueous humour after these experiments which alter the calcium level throughout the body, quite a different response takes place in the eye. Thus, Merritt and Bauer (1931) found that the administration of parathormone had little or no effect on the aqueous humour calcium, although adequate proof was present that these experiments alter the diffusible fraction of the serum calcium. As in the case of the cerebrospinal fluid the calcium of the aqueous humour remains remarkably 
constant despite well marked changes in the serum calcium level.

4. The distribution of anions.-All workers have found that there is an increased concentration of chloride in the aqueous humour. The degree of this increase will be discussed when we come to a study of the Gibbs-Donnan equilibrium. With regard to the other anions such as sulphate and phosphate, these have been found to be much lower in the aqueous humour than in plasma-findings which are not compatible with dialysis.

5. The distribution ratio of cations and ions.-Most workers agree that the product of $\mathrm{Na}$ and $\mathrm{Cl}$ in the aqueous humour is equal to that in the plasma, in these workers' opinion establishing definite proof of the dialysate nature of the intra-ocular fluid.

In an attempt to sum up what information has been obtained from a chemical study of lymph, gastric juice, and the aqueous humour, I have tried to place the various findings in a small table -see Fig. 10.

\begin{tabular}{|c|c|c|c|}
\hline & LIIPH & GASTRIC JUICE & AQUEOOS HUYODR \\
\hline $\begin{array}{l}\text { Proteln in } \\
\text { grams per. } \\
100 \text { c.c. }\end{array}$ & $\begin{array}{l}\text { May be } \\
\text { above } 1 .\end{array}$ & $\begin{array}{l}\text { Only a } \\
\text { trace. }\end{array}$ & $\begin{array}{l}\text { Only a } \\
\text { trace. } 0.02 .\end{array}$ \\
\hline $\begin{array}{l}\text { Diffusible } \\
\text { non-electro- } \\
\text { lytes such as } \\
\text { urea } \\
\text { uric acid } \\
\text { creatinine } \\
\text { sugar }\end{array}$ & $\begin{array}{l}\text { Same as in } \\
\text { plasma. Sugar } \\
\text { fol lows very } \\
\text { closely the } \\
\text { fluctations } \\
\text { of the blood } \\
\text { sugar after } \\
\text { insulin etc. }\end{array}$ & $\begin{array}{l}\text { Less than in } \\
\text { plasma. Urea } \\
50 \% \text { of plasma } \\
\text { urea. Bugar } \\
\text { appears to } \\
\text { be absent. }\end{array}$ & $\begin{array}{l}\text { Less than in } \\
\text { plaswa. They } \\
\text { average } 70 \% \\
\text { of plasma } \\
\text { concentrations. } \\
\text { Sugar does not } \\
\text { follow the } \\
\text { fuctuation } \\
\text { In the blood } \\
\text { sugar. }\end{array}$ \\
\hline $\begin{array}{l}\text { Cations such } \\
\text { as - } \\
\text { sodium } \\
\text { potassium } \\
\text { calcium }\end{array}$ & $\begin{array}{l}\text { Less than } \\
\text { in plasma. } \\
\text { Calcium fiuc- } \\
\text { tuates closely } \\
\text { w th the serum } \\
\text { calcium in } \\
\text { disturbances } \\
\text { of calcium } \\
\text { metabolism. }\end{array}$ & $\begin{array}{l}\text { Lese than } \\
\text { in plasma. }\end{array}$ & $\begin{array}{l}\text { Less than in } \\
\text { plasma. The } \\
\text { calcium does } \\
\text { not fluctuats } \\
\text { w th the serum } \\
\text { calcium. }\end{array}$ \\
\hline $\begin{array}{l}\text { Antons such } \\
\text { as - } \\
\text { chloride } \\
\text { sulphates } \\
\text { phosphates }\end{array}$ & $\begin{array}{l}\text { Yore than in } \\
\text { plasma. }\end{array}$ & $\begin{array}{l}\text { Chlorides } \\
\text { greater than } \\
\text { in plasma. } \\
\text { No analyses } \\
\text { on other } \\
\text { antons. }\end{array}$ & $\begin{array}{l}\text { Chlorides } \\
\text { greater than } \\
\text { In plasma. } \\
\text { Phosphates } \\
\text { less than in } \\
\text { plasea. } \\
\text { Sulphates less } \\
\text { than in plasma. }\end{array}$ \\
\hline $\begin{array}{l}\text { The product } \\
\text { of Na. \& Cl. } \\
\text { in terms of } \\
\text { mille equiv- } \\
\text { alents. }\end{array}$ & $\begin{array}{l}\text { Equals the } \\
\text { product of } \\
\text { Na. Cl. of } \\
\text { plasma. }\end{array}$ & $\begin{array}{l}\text { Is less than } \\
\text { the product } \\
\text { of } \mathrm{Na.} \mathrm{\&} \mathrm{Cl} \text {. } \\
\text { of plasea. }\end{array}$ & $\begin{array}{l}\text { Bquals the } \\
\text { product of } \\
\text { Da. \& Cl. or } \\
\text { plasma. }\end{array}$ \\
\hline
\end{tabular}

FIG. 10. 
The only chemical analysis of the aqueous humour in favour of simple dialysis is the fact that most workers have found that the distribution of $\mathrm{Na}$ and $\mathrm{Cl}$ is in accord with the Gibbs-Donnan equilibrium.

In conclusion I would like to refer very briefly to some experiments I have done on the chemical composition of aqueous humour and its comparison with that of the lymph, cerebro-spinal fluid and gastric juice. (Robertson and Williams, 1939).

Thoracic lymph, gastric secretion, arterial plasma, cerebrospinal fluid, and aqueous humour were collected from the same animal in a series of cases, before and at various intervals after the intravenous injection of a solution of 50 per cent. glucose, 25 per cent. urea, and 5 per cent. creatinine. In the case of the

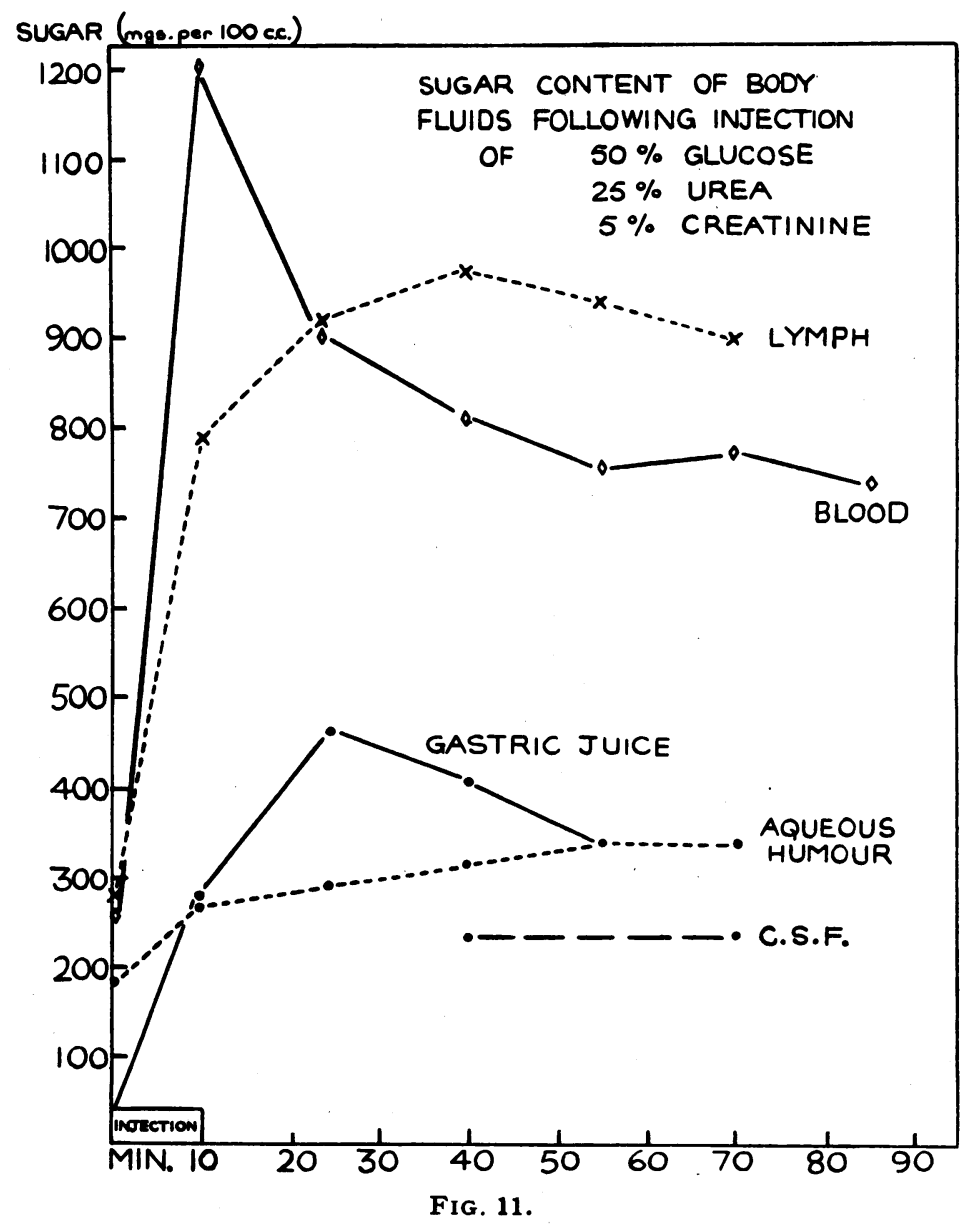

Reproduced by permission of the Editors of the Jl. of Physiol., Vol. XCV. 1939. ROBERTSON and Williams. 
aqueous humour, only two samples can be taken in an experiment -one from each eye, and in the case of cerebro-spinal fluid only one sample. Therefore, a series of animals was done in order to produce curves of the various constituents and the aqueous humour and cerebro-spinal fluid withdrawn at various intervals after the injection of the solution.

Fig. 11 shows the concentration of sugar in lymph, blood, aqueous humour, cerebro-spinal fluid, and gastric secretion.

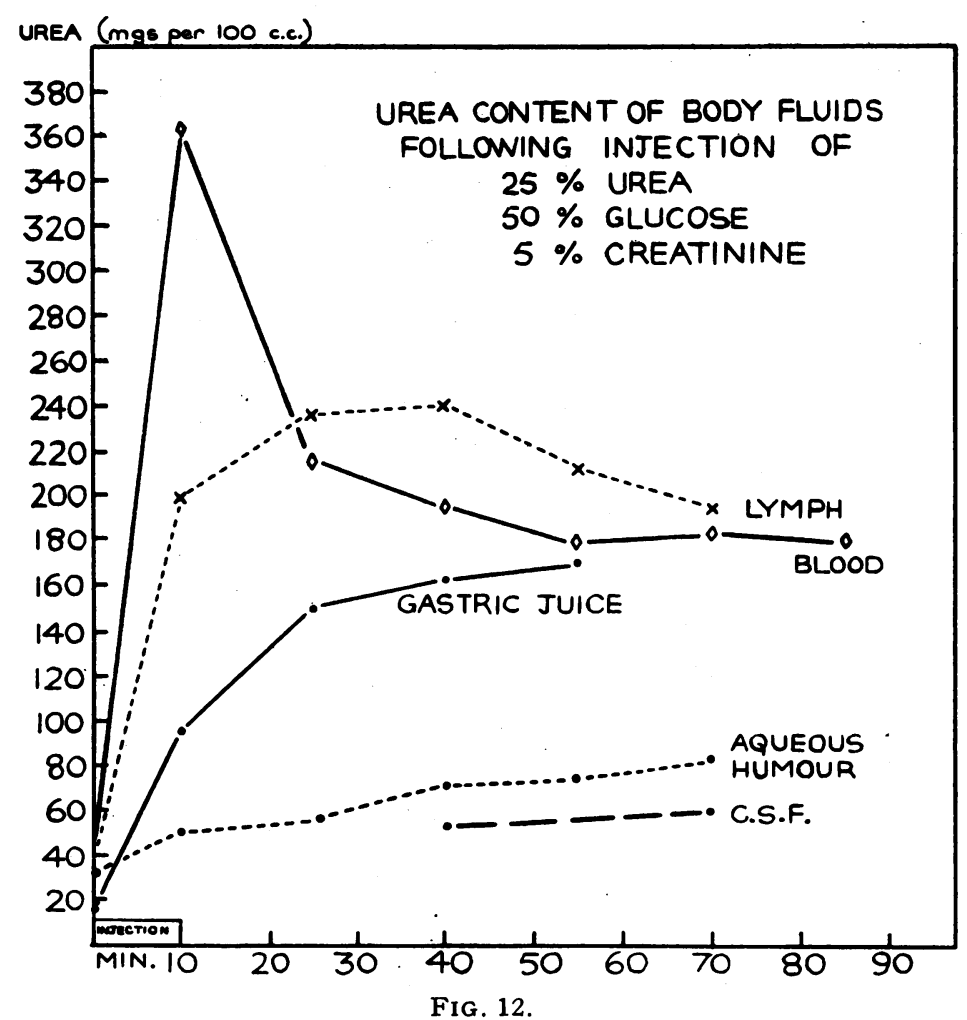

Reproduced by permission of the Editors of the $J l$. of Physiol.,

Vol XCV, 1939. ROBERTSON and WILLIAMS.

It will be seen that after the injection of glucose, the curves of lymph and plasma sugar follow one another intimately, whereas the concentration of sugar in the aqueous, cerebro-spinal fluid and gastric secretion are somewhat similar in showing a marked deficiency of at least 40 per cent. of the blood sugar level.

The following figure shows the curves of the concentrations of urea in these various body fluids.

From Fig. 12 it is once again seen that the lymph and plasma urea follow one another intimately. As in the preceding figure, however, there is a marked disparity in the urea concentrations 
of the aqueous humour, cerebro-spinal fluid and gastric secretion and the discrepancy is similar in degree in these last three fluids.

The next figure shows the curves of the concentrations of creatinine.

From Fig. 13 it will be noticed once more how similar are the curves for lymph and plasma. It is of interest to note that

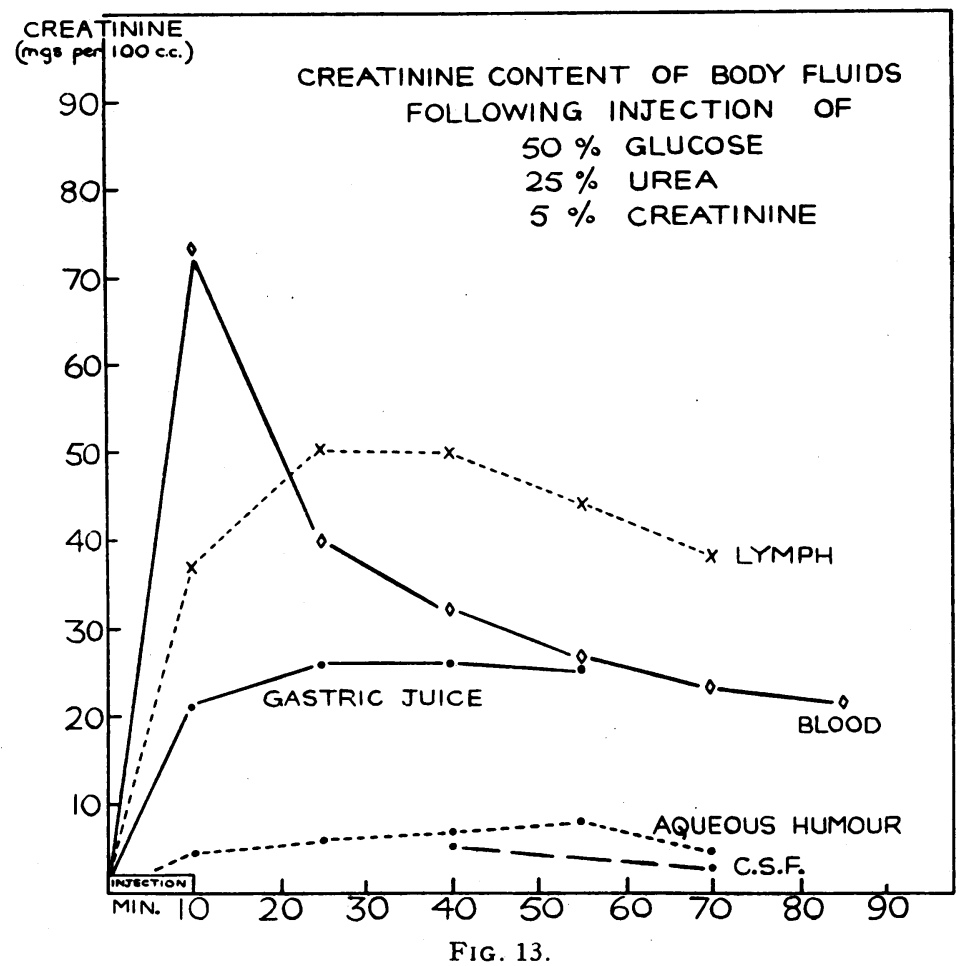

Reproduced by permission of the Editors of the $J l$. of Physiol., Vol. XCV, 1939. ROBERTSON and WILLIAMS.

creatinine diffuses through the stomach wall actually more easily than into the eye; but as in previous curves you will note a deficiency in the gastric secretion, aqueous humour, and cerebrospinal fluid when compared with plasma or lymph.

\section{Summary}

I have already stated, glucose, urea, and creatinine are freely diffusible and entirely filtrable both in vivo and in vitro so that if the membrane in the eye and the choroid plexus allowed simple dialysis to occur, these substances should occur in concentrations equal to that in the plasma; but they do not. It would appear in fact that glucose, urea, and creatinine, diffuse through the 
stomach wall with no less difficulty than they diffuse into the aqueous humour. In both the stomach and the eye, there is a marked deficiency in the urea, sugar, and creatinine concentrations when these are compared with the concentration of these substances in the blood. In the case of creatinine, all the experiments showed that this substance diffused into the stomach much more readily than into the aqueous humour. It has been stated that it is a second membrane re-inforcing the capillaries of the ciliary processes which is responsible for the low protein content of the aqueous humour, and the impaired filtration of freely diffusible substances such as urea, glucose, creatinine, and uric acid. This so-called re-inforced membrane behaves not unlike the secreting membrane present in the stomach, for it causes a similar concentration gradient for diffusible substances.

When all these facts I have mentioned are considered, it becomes clear that we cannot consider the aqueous humour a simple, protein-free. ultrafiltrate or dialysate of blood plasma, but that it is a highly specialised fluid manufactured for a specific purpose. As we found the simple laws governing the formation and absorption of tissue fluid inapplicable to the production of the aqueous humour, so we find the chemical analysis too complex to be explained by the simple laws governing the chemical equilibrium of dialysates.

\section{REFERENCES}

ARNold and MENDEL (1927).- Jl. Biol. Chem., Vol. LXXII, p. 189.

DRINKER and FIELD (1933).- - Lymphatics, Lymph and Tissue Fluid. Baillière, Tindall and Cox, London.

Gilman and Cowgill (1931-2).-Amer. Jl. of Physiol., Vol. XCIX, p. 172.

- (1933a).-Amer. Jl. of Physiol., Vol. CIII, p. 143.

(1933b).-Amer. Jl. of Physiol., Vol. CIV, p. 476.

Heim (1933).-Amer. Jl. of Physiol., Vol. CIII, p. 553.

HEIM and BERG (1933).-Amer. Il. of Physiol., Vol. CV, p. 105.

Heim, Thomson and Bartter (1935).-Amer. Jl. Physiol., Vol. CV, p. 105.

KIRBY, WIENER and Estey (1932).-Trans. Amer. Acad. of Ophthal. and Oto. p. 1 .

MerRitT and BAUER (1931).- Jl. Biol. Chem., Vol. CV, p. 233.

ROBERTSON (in press).-Brit. Jl. of Ophthal., Vol. XXIII, p. 106, 1939.

Robertson and Williams (in press).-Jl. Physiol., Vol. XCV, 1939.

TRON (1928).-Arch.f. Ophthal., Vol. CXXI, p. 329.

VAN SLYKe, HASTINGS, MURRAY and SENDROY (1925).-Jl. Biol. Chem., Vol. LXV, p. 701 .

Walker (1933).-Jl. Biol. Chem., Vol. CI, p. 269. 